\title{
Improvement of the Developmental Ability of Nuclear Transfer Embryos by Using Blastomeres from In Vitro Fertilized Embryos Selected According to the Early Developmental Stage and Cell Division Status as Donor Cells in Cattle
}

\author{
Yuji GOTO ${ }^{1,2)}$, Satoko MATOBA ${ }^{2)}$, Kei IMAI ${ }^{2)}$ and Masaya GESHI ${ }^{3)}$ \\ 1)National Institute of Livestock and Grassland Science, Nagano 389-0201, ${ }^{2)}$ National Livestock Breeding Center, \\ Fukushima 961-8511 and ${ }^{3)}$ National Institute of Livestock and Grassland Science, Ibaraki 305-0901, Japan
}

\begin{abstract}
This study was conducted to improve the developmental ability of nuclear transfer (NT) embryos by using blastomeres from in vitro fertilized (IVF) embryos with high quality as donor cells. The IVF embryos selected at the 2cell stage at 24 -h postinsemination (hpi) and again at the $\geq 8$-cell stage at 48 hpi (Selected-IVF-embryos) showed the highest blastocyst formation rate among embryos. When blastomeres from the Selected-IVF-embryos (Selected-NT group) or Nonselected-IVF-embryos (Non-selected-NT group) were used as donor cells for NT, the blastocyst formation rate in the Selected-NT group $(25.6 \%)$ was significantly higher than that in the Non-selected-NT group (13.5\%). When blastomeres from the Selected-IVF-embryos at 108 (contained many cells before cell division) and 126 hpi (contained many cells immediately after cell division) were used as donor cells for NT (108- and 126-NT groups, respectively), the 126-NT group showed a significantly higher blastocyst formation rate $(32.1 \%)$ than the $108-\mathrm{NT}$ group (16.8\%). Embryo transfer of blastocysts in the 126-NT group showed that 11 of 23 recipients became pregnant; nine calves were obtained. For the NT embryos reconstructed using in vivo derived embryos, 9 of 20 recipients became pregnant; seven calves were obtained. These results indicate that the blastocyst formation rate of NT embryos can be improved by using blastomeres from IVF embryos selected at the early developmental stage, especially immediately after cell division, and that the resultant NT embryos have a high developmental ability to progress to term that is comparable to NT embryos reconstructed using in vivo derived embryos.
\end{abstract}

Key words: Bovine, Embryo, In vitro fertilization, Nuclear transfer

(J. Reprod. Dev. 57: 249-255, 2011)

N uclear transfer (NT) technologies are now widely used by numerous laboratories to produce clone animals from embryonic and somatic cells. However, the overall efficiency of clone animal production is influenced by the different sources of donor cells; early pregnancy losses of cattle established from somatic nuclear transfer (sNT) are commonly above 50\% [1, 2], and the frequency of early fetal mortality is about two times higher with sNT than with embryonic nuclear transfer [3]. Therefore, it can be expected that a higher proportion of transferred NT embryos reconstructed from less-differentiated embryonic blastomeres would result in viable offspring compared with sNT. In addition, the production of embryonic cloned calves is permitted in Japan and food products derived from NT cattle can be on the market, thereby increasing commercial acceptance of the technology. Furthermore, the use of blastomeres from the same embryos for nuclear transfer to produce numerous identical bovine offspring is of great value for multiplication of genotypes having a superior economic value and is expected to contribute to their genetic improvement.

In NT technology using embryos at an early developmental stage as donor cells, in vitro fertilized (IVF) embryos are often used

Received: July 15, 2010

Accepted: November 14, 2010

Published online in J-STAGE: December 22, 2010

(C)2011 by the Society for Reproduction and Development

Correspondence: M Geshi (e-mail: geshi@affrc.go.jp) because they can be easily produced in vitro. However, using IVF embryos as nuclear donor cells for NT has been reported to result in a poor development of the resultant NT embryos up to the blastocyst stage compared with that of NT embryos obtained using in vivo derived donor embryos $[4,5]$. In addition, the productive efficiency of NT embryos derived from blastomeres of different IVF embryos at the same developmental stage varies considerably [6], indicating that each blastomere of different IVF embryos may have a different developmental ability; this may reflect the fact that the developmental rate of IVF embryos to the blastocyst stage is about $40 \%$ and not $100 \%$ due to malfunction of many blastomeres resulting in the death of embryos during in vitro development [7]. Therefore, the selection of blastomeres with high quality as donor cells will probably influence the development of the resultant NT embryos.

It has been reported that the cell cycle of the donor blastomeres at NT influences the developmental ability of NT embryos [8-12]. Moreover, the development of NT embryos is improved by transplanting the embryonic cells immediately after cell division to the activated recipient oocytes $[13,14]$. Thus, the cell cycle and cell division status of blastomeres as donor cells for NT may have effects on the development of the resultant NT embryos. For selection of blastomeres having a high developmental ability, it is important to select IVF embryos with a high developmental rate to the blastocyst stage. 
This study was conducted to establish a reliable selection method for IVF embryos that have a high developmental rate to the blastocyst stage and are suitable as a source of appropriate donor blastomeres for NT and to examine whether transplanting blastomeres from the selected IVF embryos improves the productive efficiency of the resultant NT embryos.

\section{Materials and Methods}

\section{In vitro maturation (IVM) and in vitro fertilization (IVF) of oocytes}

Ovaries of Japanese Black cows were collected from an abattoir and transported to the laboratory in sterile saline solution $(0.9 \%$ $\mathrm{NaCl}$ ) at $25 \mathrm{C}$. Cumulus-oocyte complexes (COCs) were aspirated from follicles 2-6 mm in diameter and put into Dulbecco's Phosphate Buffered Saline (DPBS; Invitrogen, Carlsbad, CA, USA) supplemented with 3\% calf serum (CS; Invitrogen). The COCs were washed in the in vitro maturation (IVM) medium and then placed into $100-\mu$ l drops of IVM medium under mineral oil (Nacalai Tesque, Kyoto, Japan). The IVM medium was TCM199 (Invitrogen) supplemented with 5\% CS, $100 \mathrm{IU} / \mathrm{ml}$ penicillin G (Meiji Seika, Tokyo, Japan) and $100 \mu \mathrm{g} / \mathrm{ml}$ streptomycin (Meiji Seika). The COCs were cultured in an incubator at $38.5 \mathrm{C}$ in an atmosphere of $5 \% \mathrm{CO}_{2}$ in air. Each drop of the IVM medium contained approximately 20 COCs. After 20-22 h of culture, COCs were transferred into BO medium [15] containing frozen-thawed spermatozoa from one bull that had been treated for capacitation with caffeine (10 mM; Sigma-Aldrich, St. Louis, MO, USA) and heparin (novo-heparin $1000 \mathrm{U} / \mathrm{ml}$ ) (Mochida Pharmaceutical, Tokyo, Japan) using the methods described by Niwa and Ohgoda [16]. For the experiments described below, the moment of addition of the oocytes into a suspension medium containing spermatozoa was defined as the time of insemination.

\section{Selection of IVF embryos}

Following $5 \mathrm{~h}$ of insemination, the presumptive zygotes were cultured in 100- $\mu$ l drops of in vitro culture (IVC) medium, which was composed of CR1aa medium [17] supplemented with 5\% CS, under mineral oil in a humidified atmosphere containing $5 \% \mathrm{CO}_{2}$ in air at 38.5 C. At 24-h postinsemination (hpi), the presumptive zygotes were denuded of cumulus cells by gentle pipetting. The embryos were classified based on their cell number into three groups, the 1-cell, 2-cell and more than 3-cell groups. Each group of classified embryos was transferred into 100- $\mu$ l drops of IVC medium (10 to 20 embryos/drop) and cultured separately until their subsequent classification. Each group of embryos was then classified by their cell number again at 48 hpi into two groups, the 2 to 7 cell (<8-cell) and 8-cell or more ( $\geq 8$-cell) groups. Six groups of classified embryos were cultured as a separate group in an identical IVC medium for 8 days after insemination.

\section{Source of in vivo derived embryos}

In vivo embryos were obtained from superovulated Japanese Black cattle (4.6 $\pm 1.1 \mathrm{yr}$ olds), and their blastomeres were used as donor cells for NT. Donor cows were superovulated with a decreasing $(5,5 ; 4,4 ; 3,3 \mathrm{mg}) 3$-day regimen of follicle-stimulating hormone (FSH-P; Kawasaki Pharmaceutical, Kanagawa, Japan), and $500 \mu \mathrm{g}$ cloprostenol (Estrumate; Schering-Plough Animal Health, Tokyo, Japan) was administered at $48 \mathrm{~h}$ after the first FSH$\mathrm{P}$ injection. All donor cows were observed in estrus at $48 \mathrm{~h}$ after the cloprostenol treatment and then artificially inseminated (AI) within $12 \mathrm{~h}$ with frozen semen. Nonsurgical recovery of the embryos was performed on Day 5 (Day 0 was defined as the day of AI) to collect morula-stage embryos having 16 to 32 blastomeres. These in vivo derived embryos were recovered a few hours before nuclear transfer (NT) and kept in DPBS supplemented with 20\% CS at 38.5 C until use.

\section{Method of NT}

For recipient oocytes, COCs collected as described above were matured in vitro for 20-22 h. The IVM COCs were treated in M2 medium [18] supplemented with $0.5 \%$ hyaluronidase (Sigma-Aldrich) for $5 \mathrm{~min}$. Then the cumulus cells were removed from COCs using gentle pipetting. The cumulus-free oocytes were placed in micromanipulation drops of DPBS supplemented with 20\% CS and $7.5 \mu \mathrm{g} / \mathrm{ml}$ cytochalasin B (Sigma-Aldrich) and then enucleated by pushing out a small amount of cytoplasm directly beneath the first polar body. The enucleated oocytes were activated by combined treatments with Ca-ionophore (5 $\mu \mathrm{M}$; Sigma-Aldrich) for $5 \mathrm{~min}$, a DC pulse of $0.75 \mathrm{KV} / \mathrm{cm}$ for $50 \mu$ sec (LF100, Life Tec, Tokyo, Japan) and cycloheximide (10 $\mu \mathrm{g} / \mathrm{ml}$; Sigma-Aldrich) for $6 \mathrm{~h}$ using the methods reported by Aoyagi et al. [19]. For preparation of blastomeres as donor cells, the zonae pellucidae of IVF- and in vivo derived embryos were removed by cutting with a glass needle. Blastomeres were isolated by pipetting the zona-free embryos in $\mathrm{Ca}^{2+}$ - and $\mathrm{Mg}^{2+}$-free DPBS. A blastomere was aspirated with an injection pipette and transferred to the perivitelline space of the activated oocytes. The blastomere-oocyte complexes were transferred to Zimmerman cell fusion medium [20] and then placed between the two electrodes of the fusion chamber. Membrane fusion between the enucleated recipient oocyte and blastomere was carried out by exposure to a DC pulse of $0.75 \mathrm{kV} / \mathrm{cm}$ for $50 \mu \mathrm{sec}$. One hour after the electric pulse, the fusion rates of the blastomere and recipient oocyte were evaluated using a stereomicroscope (SMZ, Nikon, Tokyo, Japan).

\section{IVC of IVF and NT embryos and their evaluation}

All the IVF and NT embryos were cultured in CR1aa medium supplemented with 5\% CS for 8 days in a humidified atmosphere containing $5 \% \mathrm{CO}_{2}$ in air at $38.5 \mathrm{C}$. The cleavage rates of the NT embryos were assessed at $48 \mathrm{~h}$ after fusion, and the developmental rates to the blastocyst stage of IVF and NT embryos after 8 days of IVC were assessed under a stereomicroscope. For counting of cell numbers, blastocysts derived from the IVF and NT embryos were stained with DPBS containing $50 \mu \mathrm{g} / \mathrm{ml}$ Hoechst 33342 (SigmaAldrich). The total cell numbers of the embryos were counted individually under an inverted microscope (Eclipse TE 300, Nikon, Tokyo, Japan) equipped with an epifluorescence (TE-FM, Nikon) and ultraviolet filter block (UV-1A, Nikon).

\section{Embryo transfer}

Recipient cows were synchronized by administration of $500 \mu \mathrm{g}$ 
cloprostenol about 3 days before the onset of desired estrus. Some reconstituted embryos that developed to the blastocyst stage at 7 or 8 day after NT were transferred nonsurgically to recipient cows at 6-8 days after estrus. One or two NT embryos per recipient were nonsurgically introduced into the uterine horn ipsilateral to the ovary containing a palpable corpus luteum. Pregnancies were determined by ultrasonography (SSD-500, Aloka, Tokyo, Japan) 30 and 60 days after embryo transfer.

\section{Experimental design}

Experiment 1: The effect of morphological selection (the number of blastomeres) of IVF embryos according to the early developmental stages on their subsequent development to the blastocyst stage was investigated. The IVF embryos were selected according to the number of blastomeres assessed twice at 24 and 48 hpi. Details were explained in the Selection of IVF embryos section above. Six groups of embryos that had been cultured separately for 8 days postinsemination were investigated for their blastocyst formation rates and total cell numbers. The group of IVF embryos showing the highest developmental rate to the blastocyst stage was defined as the Selected-IVF-embryos and used in Experiment 2.

Experiment 2: The effect of using the Selected-IVF-embryos, which were selected as 2-cell stage embryos at $24 \mathrm{hpi}$, subsequently selected again as $\geq 8$-cell stage embryos at $48 \mathrm{hpi}$ according to the same selection method used in Experiment 1 and then cultured for an additional 3 days ( 5 days in total), as a source of donor blastomeres on the development of the resultant NT embryos (Selected-NT group) was investigated; that is, the fusion rates of the donor and recipient cells and the cleavage and blastocyst formation rates of the NT embryos were investigated. The results were compared with those of NT embryos obtained using IVF embryos (16-32-cell stage) chosen at random after 5 days of IVC without selection as a source of donor blastomeres for NT (Non-selectedNT group).

Experiment 3: The precise timing of cell division for the Selected-IVF-embryos was investigated. The cell numbers of the Selected-IVF-embryos were evaluated every $6 \mathrm{~h}$ from 102-138 hpi during IVC using a fluorescent dye to monitor the cell division status of the embryos. The cell division profile of the IVF embryos at a certain time from 102-138 hpi during IVC was expressed as the ratio of the divided cells; an increased number of cells during each 6-h period of IVC out of the number of cells at the beginning of the period.

Experiment 4: The influence of the cell division stage of donor cells and the timing of NT on the developmental ability of the resultant NT embryos was investigated. When the Selected-IVFembryos had a high ratio of cell division (containing many cells immediately after cell division), they were assumed to be at the stage "after cell division". When the embryos had a low ratio of cell division (containing many cells before cell division), they were assumed to be at the stage "before cell division". Based on the results of Experiment 3, the embryos at 108 hpi and 126 hpi (108 hpi and 126 hpi groups, respectively) were used as donor embryos at the stage "before cell division" and at the stage "after cell division", respectively, for NT, and rates for the fusion of donor and recipient cells and cleavage and blastocyst formation were compared between the NT embryos obtained from the Selected-IVFembryos at the two different stages.

Experiment 5: The influence of the source of donor embryos, IVF or in vivo derived embryos, on the developmental ability of the resultant NT embryos was investigated. Based on the results of experiment 4, the Selected-IVF-embryos at 126 hpi (126-NT group) were used as a source of donor blastomeres for NT because they were proven to enhance the developmental ability of the resultant NT embryos to the blastocyst stage. In vivo derived embryos (16-cell to 32-cell stages) were used as a source of donor blastomeres for NT (In vivo-NT group). Some reconstituted NT embryos that developed to the blastocyst stage at day 7 or 8 day after NT in both groups were transferred to synchronized recipient cows. The NT embryos not used for embryo transfer were stained with fluorescent Hoechst 33342, and then the total cell numbers were counted individually under an inverted microscope equipped with epifluorescence.

\section{Statistical analyses}

Differences in fusion rates of donor and recipient cells, cleavage and blastocyst formation rates of embryos and pregnancy and calving rates among experimental groups were analyzed using chisquared analysis. The average numbers of cells per blastocyst were analyzed using one-way ANOVA. Individual comparisons between means were made using the Student's $t$-test. A value of $\mathrm{P}<0.05$ was considered to be significant.

\section{Results}

\section{Experiment 1}

A total of 382 embryos were used for selection of IVF embryos according to the number of blastomeres. The number (percentage of the total number) of IVF embryos that had been selected as 1cell, 2-cell and more than 3-cell stage embryos at 24 hpi were 63 (16.5\%), 211 (55.2\%) and 108 (28.3\%), respectively. The developmental rate to the blastocyst stage of the selected IVF embryos is shown in Table 1 . The developmental rate to the blastocyst stage (84.3\%) of embryos that had been selected as 2-cell stage embryos at $24 \mathrm{hpi}$, and then selected again as $\geq 8$-cell stage embryos at $48 \mathrm{hpi}$ (the Selected-IVF group) was significantly higher than those of the other groups after selection (0-39.6\%) and that of the Nonselected-IVF group (44.2\%) calculated based on the total number of embryos produced without selection $(\mathrm{P}<0.05)$. These blastocysts had a significantly higher number of cells (108.6) than those of the embryos from the other groups (42.3-67.3; $\mathrm{P}<0.05)$.

\section{Experiment 2}

Table 2 shows the fusion rates of donor and recipient cells and the cleavage and blastocyst formation rates of NT embryos from the Non-selected-NT and Selected-NT groups. No differences were observed in the fusion or cleavage rate between the two NT groups. However, the blastocyst formation rate of the NT embryos from the Selected-NT group (25.6\%) was significantly higher than that of the Non-selected-NT group (13.5\%; $\mathrm{P}<0.05)$. 
Table 1. Effects of selection of in vitro fertilized (IVF) embryos according to the number of blastomeres at 24 and $48 \mathrm{~h}$ postinsemination on subsequent in vitro development to the blastocyst stage* in cattle

\begin{tabular}{|c|c|c|c|c|c|c|}
\hline \multicolumn{2}{|c|}{$\begin{array}{l}\text { Selection of embryos according } \\
\text { to No. of blastomeres** }\end{array}$} & \multirow[t]{2}{*}{$\begin{array}{l}\text { No. of } \\
\text { replicates }\end{array}$} & \multirow[t]{2}{*}{ No. of embryos } & \multirow{2}{*}{\multicolumn{2}{|c|}{$\begin{array}{l}\text { No. of blastocysts } \\
(\%)\end{array}$}} & \multirow[t]{2}{*}{$\begin{array}{l}\text { Mean no. of cells per } \\
\text { blastocyst (mean } \pm \text { SD) }\end{array}$} \\
\hline $24 \mathrm{~h}$ & $48 \mathrm{~h}$ & & & & & \\
\hline$\geq 3$ & $\geq 8$ & 4 & 71 & 25 & $(35.2)^{\mathrm{a}}$ & $57.4 \pm 20.7^{a}$ \\
\hline$\geq 3$ & $<8$ & 4 & 37 & 9 & $(24.3)^{\mathrm{a}}$ & $42.3 \pm 7.1^{\mathrm{a}}$ \\
\hline 2 & $\geq 8$ & 4 & 115 & 97 & $(84.3)^{\mathrm{b}}$ & $108.6 \pm 33.3^{b}$ \\
\hline 2 & $<8$ & 4 & 96 & 38 & $(39.6)^{\mathrm{a}}$ & $67.3 \pm 26.9^{\mathrm{a}}$ \\
\hline 1 & $\geq 8$ & 4 & 33 & 0 & $(0)^{\mathrm{c}}$ & - \\
\hline 1 & $<8$ & 4 & 30 & 0 & $(0)^{\mathrm{c}}$ & - \\
\hline \multicolumn{2}{|c|}{ Total } & 4 & 382 & 169 & $(44.2)^{\mathrm{a}}$ & $88.2 \pm 28.6^{a}$ \\
\hline
\end{tabular}

* All the IVF embryos were cultured for 8 days in total. ** The number of blastomeres in IVF embryos observed at 24 and $48 \mathrm{~h}$ postinsemination. ${ }^{a, b, c}$ Values within the same columns with different superscripts significantly differ $(\mathrm{P}<0.05)$.

Table 2. Effects of selection of in vitro fertilized embryos as donor embryos for nuclear transfer (NT) on subsequent in vitro development of NT embryos to the blastocyst stage in cattle

\begin{tabular}{lccccc}
\hline $\begin{array}{l}\text { Source of donor } \\
\text { embryos }\end{array}$ & $\begin{array}{c}\text { No. of } \\
\text { replicates }\end{array}$ & $\begin{array}{c}\text { No. of } \\
\text { recipient oocytes }\end{array}$ & $\begin{array}{c}\text { No. of fused } \\
\text { oocytes (\%) }\end{array}$ & $\begin{array}{c}\text { No. of cleaved } \\
\text { embryos }^{+}(\%)\end{array}$ & $\begin{array}{c}\text { No. of } \\
\text { blastocysts }^{++}(\%)\end{array}$ \\
\hline $\begin{array}{l}\text { Selected-IVF } \\
*\end{array}$ & 4 & 150 & $125(83.3)$ & $105(84.0)$ & $32(25.6)^{\mathrm{a}}$ \\
Non-selected-IVF** & 4 & 130 & $104(80.0)$ & $87(83.7)$ & $14(13.5)^{\mathrm{b}}$ \\
\hline
\end{tabular}

* Selected-IVF: In vitro fertilized bovine embryos, which had been selected as 2-cell stage embryos at 24 h post insemination (hpi) and subsequently selected again as $\geq 8$-cell stage embryos at $48 \mathrm{hpi}$, were cultured for additional 3 days ( 5 days in total). ** Nonselected-IVF: In vitro fertilized bovine embryos (16-32-cell stage) chosen at random after 5 days of in vitro culture without selection. ${ }^{+}$The cleavage rates of NT embryos were assessed at $48 \mathrm{~h}$ after fusion. ${ }^{++}$The developmental rates to the blastocyst stage of NT embryos were assessed after 8 days of in vitro culture. a,b Values with different superscripts within the same column significantly differ $(\mathrm{P}<0.05)$.

\section{Experiment 3}

The total cell numbers of the Selected-IVF-embryos, evaluated every $6 \mathrm{~h}$ from 102-138 hpi (36 h) during IVC, are shown in Fig. 1. The average cell number increased from 17.9 to 51.3 cells during the $36 \mathrm{~h}$. The ratios of divided cells were $8.7-28.9 \%$ during each $6-$ $\mathrm{h}$ period of IVC. A high ratio of cell division was observed from 120-126 hpi during IVC (28.9\%). In contrast, a low ratio of cell division was observed from 102-108 hpi during IVC (8.7\%). Thus, it can be suggested that the embryos at $108 \mathrm{hpi} \mathrm{(108} \mathrm{hpi} \mathrm{group)}$ contain many cells before cell division. In contrast, the embryos at 126 hpi (126 hpi group) contain many cells that divided within $6 \mathrm{~h}$ before. Thus, they should contain many cells just after cell division.

\section{Experiment 4}

The developmental abilities of the NT embryos produced by using different sources of donor cells at two different cell division stages, the before cell division (108 hpi group) and after cell division (126 hpi group) stages, are shown in Table 3. No differences were observed for the fusion rate of donor and recipient cells and the cleavage rate after NT, but the blastocyst formation rate for the 126 hpi group (32.1\%) was significantly higher than that for the 108 hpi group $(16.8 \%, \mathrm{P}<0.05)$.

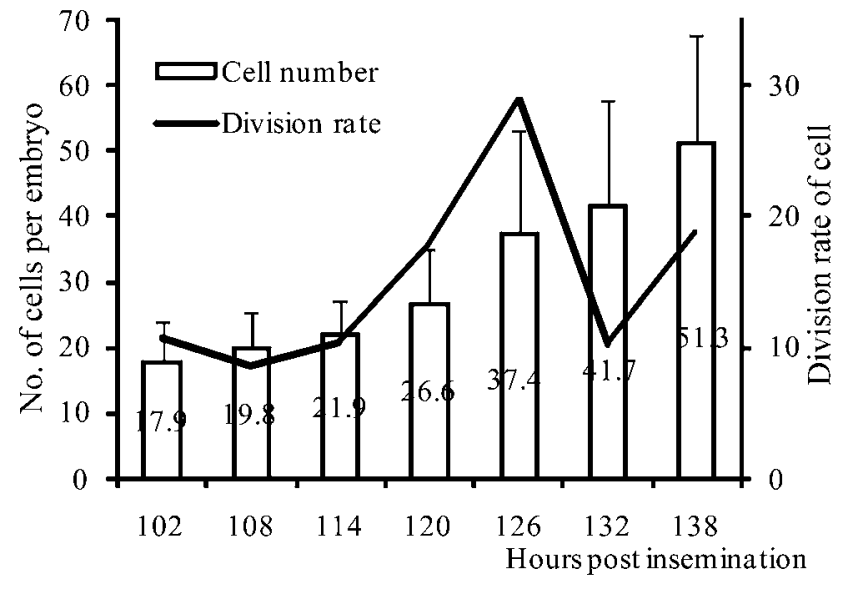

Fig. 1. Number of cells in in vitro fertilized embryos and their rate of cell division according to postinsemination time. The cell number of the Selected-IVF-embryos was evaluated every $6 \mathrm{~h}$ from 102-138 hpi during in vitro culture (IVC) to evaluate the cell division status of the embryos. The cell division profile of IVF embryos at a certain time from 102-138 hpi during IVC was expressed as the ratio of the divided cells, an increased number of cells during each 6-h period of IVC out of the number of cells at the beginning of the period. 
Table 3. Effects of the different cell division stages of the Selected-IVF-embryos* as donor embryos on the developmental ability of the nuclear transfer (NT) embryos in cattle

\begin{tabular}{lccccc}
\hline $\begin{array}{l}\text { Source of donor embryos: } \\
\text { Selected-IVF-embryos } \\
\text { cultured for }\end{array}$ & $\begin{array}{c}\text { No. of } \\
\text { replicates }\end{array}$ & $\begin{array}{c}\text { No. of } \\
\text { oocytes }\end{array}$ & $\begin{array}{c}\text { No. of fused } \\
\text { oocytes } \\
(\%)\end{array}$ & $\begin{array}{c}\text { No. of cleaved } \\
\text { embryos }^{+} \\
(\%)\end{array}$ & $\begin{array}{c}\text { No. of } \\
\text { blastocysts }^{++} \\
(\%)\end{array}$ \\
\hline $108 \mathrm{~h}^{* *}$ & 6 & 178 & $155(87.1)$ & $123(79.4)$ & $26(16.8)^{\mathrm{a}}$ \\
$126 \mathrm{~h}^{* * *}$ & 6 & 196 & $168(85.7)$ & $136(81.0)$ & $54(32.1)^{\mathrm{b}}$ \\
\hline
\end{tabular}

* Selected-IVF-embryos: In vitro fertilized bovine embryos, which had been selected as 2-cell stage embryo at $24 \mathrm{~h}$ post insemination (hpi) and subsequently selected again as $\geq 8$-cell stage embryos at $48 \mathrm{hpi}$, were cultured for 108 or $126 \mathrm{~h}$ in total. ** The Selected-IVFembryos at 108 hpi having many cells before cell division. *** The Selected-IVF-embryos at 126 hpi having many cells after cell division. ${ }^{+}$The cleavage rates of NT embryos were assessed at $48 \mathrm{~h}$ after fusion. ${ }^{++}$The developmental rates to the blastocyst stage of NT embryos were assessed after 8 days of in vitro culture. ${ }^{\mathrm{a}, \mathrm{b}}$ Values with different superscripts within the same column significantly differ $(\mathrm{P}<0.05)$.

Table 4. Comparison of developmental ability to the blastocyst stage and to progress to term after embryo transfer of nuclear transfer (NT) embryos produced by using the Selected-IVF-embryos and in vivo produced embryos as donor embryos

\begin{tabular}{lcccccccc}
\hline $\begin{array}{l}\text { Source of } \\
\text { donor } \\
\text { embryos }\end{array}$ & $\begin{array}{c}\text { No. of } \\
\text { replicates }\end{array}$ & $\begin{array}{c}\text { No. of } \\
\text { recipient } \\
\text { oocytes }\end{array}$ & $\begin{array}{c}\text { No. of fused } \\
\text { oocytes } \\
(\%)\end{array}$ & $\begin{array}{c}\text { No. of cleaved } \\
\text { embryos } \\
(\%)\end{array}$ & $\begin{array}{c}\text { No. of } \\
\text { blastocysts } \\
(\%)\end{array}$ & $\begin{array}{c}\text { Mean no. of cells } \\
\text { per blastocyst } \\
\text { (mean } \pm \text { SD) }\end{array}$ & $\begin{array}{c}\text { No. of pregnancies/ } \\
\text { No. of transfers } \\
\text { (\%) }\end{array}$ & $\begin{array}{c}\text { No. of calves/ } \\
\text { No. of transfers } \\
(\%)\end{array}$ \\
\hline $\begin{array}{l}\text { Selected-IVF-embryos* } \\
\text { In vivo produced embryos** }\end{array}$ & 5 & 118 & $103(87.3)$ & $84(81.6)$ & $42(40.8)$ & $86.5 \pm 16.0$ & $11 / 23(47.8)$ & $9 / 23(39.1)$ \\
9 & 130 & $106(81.5)$ & $89(84.0)$ & $38(35.8)$ & $83.1 \pm 17.3$ & $9 / 20(45.0)$ & $7 / 20(35.0)$ \\
\hline
\end{tabular}

*Selected-IVF-embryos: In vitro fertilized bovine embryos, which had been selected as 2-cell stage embryo at 24 h post insemination (hpi) and subsequently selected again as $\geq 8$-cell stage embryos at $48 \mathrm{hpi}$, were cultured for $126 \mathrm{~h}$ in total. **In vivo produced embryos: 16-cell to 32-cell stage embryos were collected using a nonsurgical flushing from superovulated cows 5 days after artificial insemination. ${ }^{+}$The cleavage rates of NT embryos were assessed at $48 \mathrm{~h}$ after fusion. ${ }^{++}$The developmental rates to the blastocyst stage of NT embryos were assessed after 8 days of in vitro culture.

\section{Experiment 5}

The developmental abilities of the NT embryos produced by using the Selected-IVF-embryos at $126 \mathrm{~h}$ of IVC or the in vivo derived embryos as a source of donor blastomeres for NT are shown in Table 4. No difference was observed in the fusion rate of donor and recipient cells and the cleavage or blastocyst formation rate between the NT embryos derived from both sources of embryos. Also, there was no difference in the average cell number between the blastocysts. NT blastocysts obtained from the Selected IVF-embryos at $126 \mathrm{hpi}$ (126 hpi group) were transferred to 23 recipients (1 blastocyst was transferred to 18 cows, and 2 blastocysts were transferred to 5 cows), and 11 of them became pregnant. Nine recipients carried to full term, but two recipients aborted. NT embryos derived from in vivo derived embryos were transferred to 20 recipients ( 1 blastocyst was transferred to 16 cows, and 2 blastocysts were transferred to 4 cows), and 9 of them became pregnant. Seven recipients carried to full term, but two recipients aborted. Five males and four females were obtained in the 126 hpi-NT group, and four males and three females were obtained in the In vivo-NT group. A total of 16 calves were obtained in the 2 groups, and all of them were morphologically normal. The mean birth weights of the nuclear transfer calves of the $126 \mathrm{hpi}-\mathrm{NT}$ and In vivo-NT groups were $37.9 \pm 9.2 \mathrm{~kg}$ and $35.7 \pm 7.0 \mathrm{~kg}$ respectively.

\section{Discussion}

Our results demonstrate that the blastocyst formation rate of NT embryos can be improved by using blastomeres from IVF embryos selected at the early developmental stage and that the resultant NT embryos have a high developmental potential to go to term that is comparable to NT embryos reconstructed using in vivo derived embryos. The reason for this improvement must have been the selection of IVF embryos used as donor embryos. To our knowledge, this is the first to report showing that the same pregnancy rates can be obtained after ET of NT embryos produced by using IVF and in vivo derived embryos as the source of donor blastomeres.

Many reports have described that the timing of first cleavage after IVF has a major effect on subsequent in vitro development of embryos [21-26]. In particular, the developmental rate to the blastocysts stage was significantly higher for embryos that cleaved early after 24-30 h of insemination than those of embryos that cleaved slowly [21-23]. Besides, it has also been reported that the blastocyst formation rates of IVF embryos were different according to the developmental stage after $60 \mathrm{~h}$ of insemination; the time at which the blastocyst formation rate was checked was later than that reported above [27]. Thus, we compared the blastocyst formation rates of IVF embryos selected according to the number of blastomeres assessed at $24 \mathrm{~h}$ (around the first cleavage) and $48 \mathrm{~h}$ (around the third cleavage), and then the embryos were cultured in vitro for 8 days in total. It was found that the developmental rate to the blastocyst stage of embryos that had been selected as 2-cell stage embryos at $24 \mathrm{hpi}$ and then selected again as $\geq 8$-cell stage embryos at 48 hpi (the Selected-IVF group) was significantly higher than those of the other groups. Although it was previously reported that the blastocyst formation rates of embryos selected as 
2-cell stage embryos at 24 and 30 hpi were 52\% [25] and 65.7\% [24], respectively, and higher than those of other embryos, only one selection was used in those reports, and the rates seem to be lower than those obtained in the present study. Furthermore, when the blastocyst formation rates were recalculated according to selection only at $24 \mathrm{hpi}$ in the present study, the rate of IVF embryos selected as 2-cell stage embryo that developed to the blastocyst stage was $64.0 \%$ and significantly lower than that of the IVF embryos selected twice at 24 and 48 hpi. Thus, it can be concluded that the developmental rate to the blastocyst stage and the quality of the IVF embryos were effectively improved by the two selections of the IVF embryos according to the early developmental stage.

In the present study, a significant decrease of the blastocyst formation rate was observed for the IVF embryos having more than 3 blastomeres at $24 \mathrm{hpi}$ irrespective of number of blastomeres at 48 hpi compared with the Selected-IVF group. Also, IVF embryos having 2 blastomeres at 24 hpi and less than 8 blastomeres at 48 hpi showed a significantly lower blastocyst formation rate compared with the Selected-IVF group. Thus, 2 consecutive selections of IVF embryos would be important to make sure that the selected embryos have the proper timing of cleavages that will result in high developmental ability and the desired quality for NT. In contrast, Ulloa et al. [28] reported that the blastocyst formation rates of $>8$ cell stage embryos at 48 hpi were lower than those of 5-cell to 8cell stage bovine embryos and that the incidence of chromosomal abnormalities of $>8$-cell stage embryos at 48 hpi was significantly higher than those of 5-cell to 8-cell stage embryos. In our study, IVF embryos having more than 8 blastomeres at 48 hpi were hardly observed in the embryos selected as 2-cell stage embryos at $24 \mathrm{hpi}$, but they were observed in the embryos selected as more than 3-cell stage embryos at $24 \mathrm{hpi}$. Thus, it seemed that IVF embryos having more than 3 blastomeres at 24 hpi corresponded to the embryos having more than 8 blastomeres at $48 \mathrm{hpi}$ in the report by Ulloa et al. [28]. As for the IVF embryos with an especially high cleavage speed postinsemination, the developmental rate to the blastocyst stage seemed to be low.

Zakhartchenko et al. [6] reported that the developmental rate to the blastocyst stage of NT embryos was different according to the size of blastomeres used as donor cells. Although the blastomeres they obtained were from the same stage embryos, the NT embryos derived from small blastomeres showed a significantly higher blastocyst formation rate than the NT embryos derived from larger blastomeres. They suggested that small blastomeres were superior as donor cells for NT because they have greater developmental ability than larger blastomeres. Although the sizes of the blastomeres were not measured in the present study, it can be also suggested that the developmental potential of NT embryos was improved by using the Selected-IVF-embryos as donor embryos because they were estimated to contain a lot of blastomeres with a greater developmental ability.

Smith et al. (1988) reported that cell cycle synchronous transplantation between the donor nucleus and cytoplasm is important for the development of reconstituted mouse NT embryos [29]. Furthermore, it was reported that the cell cycle stage of nuclear donor cells at the time of NT influenced the development of reconstituted NT embryos in cows [9-11], rabbits [8] and mice [12]. On the other hand, the use of enucleated and activated oocytes as recipient cytoplasts resulted in an increased frequency of development to the blastocyst stage of embryos reconstituted from unsynchronized donor nuclei from totipotent cell types [19, 30-32]. Furthermore, when the synchronized donor cells were transplanted into activated oocytes, the cell stage of the donor blastomeres immediately after division improved the blastocyst formation rate of the NT embryos $[12,13]$. Thus, in the present study, we used enucleated and activated IVM oocytes as recipient cytoplasts and estimated the suitable IVF embryos as donor embryos for NT. The present results similarly showed that the blastocyst formation rate of NT embryos was higher using IVF embryos having many cells immediately after cell division as the source of donor cells. Activated recipient cytoplasts are presumed to be at the S-phase with a low level of maturation promoting factor [33]. On the other hand, the G1-phase period of donor embryonic nuclei is very short and immediately shifts to the S-phase of the cell cycle [33, 34]. Therefore, the Selected-IVF-embryos just after cell division were used as the source of donor cells in the present study because many of their blastomeres should be at the S-phase. In the present study, although the cell cycle was not confirmed and the definite stage of the cell cycle of the blastomeres used as donor cells was uncertain, it was suggested that the early cell cycle stage after cell division improved the blastocyst formation rate of the NT embryos based on investigation of the cell division ratio of the donor embryos. Moreover, the donor embryos were selected twice or 3 times at the early cleavage stage in the present study. Therefore, it was thought that the Selected-IVF-embryos were at a similar developmental stage and that their cell division had been well synchronized.

When the Selected-IVF-embryos were used for NT, the blastocyst formation rates and total cell numbers of the NT embryos were similar to those of NT embryos obtained from the in vivo derived embryos. Moreover, when the obtained blastocysts were transplanted into recipient cows, the productive efficiency of the clone calves was similar to that of NT embryos derived from in vivo derived embryos.

In conclusion, when a blastomere from an IVF embryo was used as a donor cell for NT, the blastocyst formation rate of the NT embryo was improved by transplanting the nucleus from an IVF embryo selected according to the morphological development patterns in the early development stage and just after cell division. The resultant NT embryos have a high developmental ability to progress to term after embryo transfer that is comparable to NT embryos reconstructed using in vivo derived embryos.

\section{Acknowledgments}

We would like to express our thanks to Dr T Nagai (National Institute of Livestock and Grassland Science, Tsukuba, Japan) for critical and useful comments on the manuscript.

\section{References}

1. Cibelli JB, Stice SL, Golueke PJ, Kane JJ, Jerry J, Blackwell C, Ponce de Leon FAP, Robl JM. Cloned transgenic calves produced from nonquiescent fetal fibroblast. Science 1998; 280: 1256-1258.

2. Wells DN, Misica PM, Tervit HR. Production of cloned calves following nuclear 
transfer with cultured adult mural granulose cells. Biol Reprod 1999; 60: 996-1005.

3. Heyman Y, Chavatte-Palmer P, LeBourhis D, Camous S, Vignon X, Renard JP. Frequency and occurrence of late-gestation losses from cattle cloned embryos. Biol Reprod 2002; 66: 6-13.

4. Yang X, Jiang S, Farrell P, Foote RH, McGrath A. Nuclear transfer in cattle: effect of nuclear donor cells, cytoplast age, co-culture, and embryo transfer. Mol Reprod Dev 1993; 35: 29-36.

5. Clement-Sengewald A, Palma GA, Berg U, Brem G. Comparison between in vitro produced and in vivo flushed donor embryos for cloning experiments in cattle. Theriogenology 1992; 37: 196 abstr.

6. Zakhartchenko V, Wolf E, Palam GA, Brem G. Effect of donor embryo cell number and cell size on the efficiency of bovine embryo cloning. Mol Reprod Dev 1995; 42: 5357.

7. Rizos D,Ward F, Duffy P, Boland MP, Lonergan P. Consequences of bovine oocyte maturation, fertilization or early embryo development in vitro versus in vivo: implications for blastocyst yield and blastocyst quality. Mol Reprod Dev 2002; 61: 234-248.

8. Collas P, Balise JJ, Roble JM. Influence of cell cycle stage of the donor nucleus on development of nuclear transplant rabbit embryos. Biol Reprod 1992; 46: 492-500.

9. Stice SL, Keefer CL, Maki-Laurila M, Matthews L. Donor blastomere cell cycle stage affects developmental competence of bovine nuclear transfer embryos. Theriogenology 1993; 39: 318 abstr.

10. Campbell KHS, Ritchie WA, Wilmut I. Nuclear-cytoplasmic interactions during the first cell cycle of nuclear transfer reconstructed bovine embryos: Implications for deoxyribonucleic acid replication and development. Biol Reprod 1993; 49: 933-942.

11. Techakumphu M, Adenot P, Chesne P, Rao VH, Heyman Y, Renard JP. Viability of bovine blastomeres after metaphase arrest with nocodazole. Theriogenology 1993; 39: 328 abstr.

12. Cheong HT, Takahashi $\mathbf{Y}$, Kanagawa H. Birth of mice after transplantation of early cell-cycle-stage embryonic nuclei into enucleated oocytes. Biol Reprod 1993; 48: 958963.

13. Tanaka $\mathbf{H}$, Kanagawa $\mathbf{H}$. Influence of combined activation treatments on the success of bovine nuclear transfer using young or aged oocytes. Anim Reprod Sci 1997; 49: 113123.

14. Tanaka H. Influence of the timing of blastomere isolation after the removal of nocodazole in bovine nuclear transfer. Theriogenology 1999; 51: 1225-1237.

15. Brackett BG, Oliphant G. Capacitation of rabbit spermatozoa in vitro. Biol Reprod 1975; 12: 260-274.

16. Niwa K, Ohgoda O. Synergistic effect of caffeine and heparin on in-vitro fertilization of cattle oocytes matured in culture. Theriogenology 1988; 30: 733-741.

17. Rosenkrans CFJ, Zeng GQ, MCNamara GT, Schoff PK, First NL. Development of bovine embryos in vitro as affected by energy substrates. Biol Reprod 1993; 49: 459-462.

18. Quinn P, Barros C, Whittingham DG. Preservation of hamster oocytes to assay the fertilizing capacity of human spermatozoa. J Reprod Fertil 1982; 66: 161-168.

19. Aoyagi Y, Konishi M, Wada T, Takedomi T. Unaged bovine oocytes successfully develop to blastocysts after parthenogenic activation or nuclear transfer. Theriogenology 1994; 41 : 157 abstr.

20. Wolfe BA, Kraemer DC. Methods in bovine nuclear transfer. Theriogenology 1992; 37 5-15.

21. Van Soom A, Van Vlaenderen I, Mahmoudzadeh AR, Deluyker H, de Kruif A Compaction rate of in vitro fertilized bovine embryos related to the interval from insemination to first cleavage. Theriogenology 1992; 38: 905-919.

22. Lonergan P, Piumi F, Humblot P. Effect of time interval from insemination to first cleavage on the development of bovine embryos in vitro and in vivo. Theriogenology 1999; 51: 326 abstr.

23. Rieger D, Lonergan P, Boland MP. The relationship between the time of first cleavage of cattle oocytes and subsequent development to the blastocyst stage. Theriogenology 1999; 51: 190 abstr.

24. Plante L, King WA. Effect of time first cleavage on hatching rate of bovine embryos in vitro. Theriogenology 1992; 37: 274 abstr.

25. Dinnyes A, Lonergan P, Fair T, Boland MP, Yang X. Timing of the first cleavage postinsemination affects cryosurvival of in vitro-produced bovine blastocysts. Mol Reprod Dev 1999; 53: 318-324.

26. Ward F, Rizos D, Corridan D, Quinn K, Boland M, Lonergan P. Paternal influence on the time of first embryonic cleavage post insemination and the implications for subsequent bovine embryo development in vitro and fertility in vivo. Mol Reprod Dev 2001 60: 47-55.

27. Hernandez-Ledezma JJ, Villanueva C, Sikes JD, Kubisch HM. Increasing the rate of blastocyst formation and hatching from in vitro-produced bovine zygotes. Theriogenology 1996; 46: 961-969.

28. Ulloa CMU, Yoshizawa M, Yamashita A, Hama S, Mitsui A, Hashi C, Abe H, Hosh $\mathrm{H}$, Fukui E, Matsumoto H. Blastocyst production from in vitro-produced day-2 bovine embryos classified by cleavage stage, and cytogenetical evaluation of the resultant day-8 blastocysts. J Reprod Dev 2008; 54: 465-472.

29. Smith LC, Wilmut I, Hunter RHF. Influence of cell cycle stage at nuclear transplantation on the development in vitro of mouse embryos. J Reprod Fertil 1988; 84: 619-624.

30. Stice SL, Keefer CL, Matthews L. Bovine nuclear transfer embryos: Oocyte activation prior to blastomere fusion. Mol Reprod Dev 1993; 39: 61-68.

31. Ushijima $\mathbf{H}$, Eto T. Bovine nuclear transfer using parthenogenetically activated oocytes as recipient cytoplast. Theriogenology 1993; 39: 333 abstr.

32. Kono T, Sotomaru Y, Aono F, Takahashi T, Ogiwara I, Sekizawa F, Arai T, Nakahara T. Effect of ooplast activation on the development of oocytes following nucleus transfer in cattle. Theriogenology 1994; 41: 1463-1471.

33. Barnes FL, Collas P, Powell R, King WA, Westhusin M, Shepherd D. Influence of recipient oocyte cell cycle stage on DNA synthesis, nuclear envelope breakdown, chromosome constitution, and development in nuclear transplant bovine embryos. Mol Reprod Dev 1993; 36: 33-41.

34. Barnes FL, Eyestone WH. Early cleavage and the maternal zygotic transition in bovine embryos. Theriogenology 1990; 33: 141-152. 